\title{
Present and historical landscape structure shapes current species richness in Central European grasslands
}

\author{
Pascal Scherreiks (i) - Martin M. Gossner • Didem Ambarlı • Manfred Ayasse • \\ Nico Blüthgen - Markus Fischer • Valentin H. Klaus • Till Kleinebecker • \\ Felix Neff - Daniel Prati - Sebastian Seibold • Nadja K. Simons • \\ Wolfgang W. Weisser $\cdot$ Konstans Wells $\cdot$ Catrin Westphal $\cdot$ Jan Thiele
}

Received: 17 May 2021 / Accepted: 24 December 2021 / Published online: 12 January 2022

(C) The Author(s) 2022

\begin{abstract}
Context Current diversity and species composition of ecological communities can often not exclusively be explained by present land use and landscape structure. Historical land use may have considerably influenced ecosystems and their properties for decades and centuries.

Objectives We analysed the effects of present and historical landscape structure on plant and arthropod species richness in temperate grasslands, using data
\end{abstract}

Supplementary Information The online version contains supplementary material available at https://doi.org/10.1007/ s10980-021-01392-7.

P. Scherreiks $(\bowtie) \cdot J$. Thiele

Thünen Institute of Biodiversity, Bundesallee 65,

38116 Brunswick, Germany

e-mail: pascal.scherreiks@thuenen.de

P. Scherreiks

Department of Architecture, Civil Engineering and Environmental Sciences, Technical University of Brunswick, Katharinenstraßer 3, 38106 Brunswick, Germany

M. M. Gossner · F. Neff

Forest Entomology, WSL Swiss Federal Research Institute, Zürcherstrasse 111, 8903 Birmensdorf,

Switzerland

M. M. Gossner

Department of Environmental Systems Science, Institute of Terrestrial Ecosystems, ETH Zurich, 8092 Zurich, Switzerland from comprehensive plant and arthropod assessments across three regions in Germany and maps of current and historical land cover from three time periods between 1820 and 2016.

Methods We calculated local, grassland class and landscape scale metrics for 150 grassland plots. Class and landscape scale metrics were calculated in buffer zones of 100 to $2000 \mathrm{~m}$ around the plots. We considered effects on total species richness as well as on the richness of species subsets determined by taxonomy and functional traits related to habitat use, dispersal and feeding.

\footnotetext{
D. Ambarlı . W. W. Weisser

Terrestrial Ecology Research Group, Department of Ecology and Ecosystem Management, Technical University of Munich, Hans-Carl-von-Carlowitz-Platz 2, 85354 Freising, Germany

D. Ambarl1

Department of Agricultural Biotechnology, Faculty of Agriculture, Düzce University, 81620 Düzce, Turkey

M. Ayasse

Institute of Evolutionary Ecology and Conservation Genomics, University of Ulm, Albert-Einstein-Allee 1, 89075 Ulm, Germany

N. Blüthgen · N. K. Simons

Ecological Networks, Technische Universität Darmstadt, Schnittspahnstraße 3, 64287 Darmstadt, Germany
} 
Results Overall, models containing a combination of present and historical landscape metrics showed the best fit for several functional groups. Comparing three historical time periods, data from the $1820 / 50$ s was among the most frequent significant time periods in our models (29.7\% of all significant variables).

Conclusions Our results suggest that the historical landscape structure is an important predictor of current species richness across different taxa and functional groups. This needs to be considered to better identify priority sites for conservation and to design biodiversity-friendly land use practices that will affect landscape structure in the future.

Keywords Species richness - Landscape metrics · GLM · Land-use intensity · Historical landscape structure $\cdot$ Landscape configuration · Landscape composition

\section{Introduction}

Semi-natural grasslands are among the most species rich ecosystems in Central Europe (Habel et al. 2013). Since those grasslands are part of the cultivated landscape in Germany, abandoning them would lead to scrub encroachment and eventually to forests, culminating in the loss of culturally important and biologically diverse ecosystems. Over the last decades, European grasslands, their communities and related ecological processes have been facing various

M. Fischer - D. Prati

Institute of Plant Science, University of Bern,

Alternbergrain 21, 3013 Bern, Switzerland

\section{H. Klaus}

Department of Environmental Systems Science, Institute of Agricultural Sciences, ETH Zurich, Universitätstr. 2, 8092 Zurich, Switzerland

\section{T. Kleinebecker}

Institute of Landscape Ecology and Resources

Management, Justus-Liebig-University Gießen, Heinrich-

Buff-Ring 26-32, 35392 Gießen, Germany

\section{S. Seibold}

Ecosystem Dynamics and Forest Management Research Group, School of Life Science, Technical University of Munich, Hans-Carl-von-Carlowitz-Platz 2,

85354 Freising, Germany threats and challenges, such as management adaptations to changing socio-economic conditions, leading to intensification or abandonment. A consequence of intensifying fertilization practises on neighbouring fields is a decrease in soil moisture and an increase in soil nutrient availability. (e.g. Biró et al. 2013; Diekmann et al. 2019). Thus, species adapted to low-intensity land use over long time periods (Pärtel et al. 2005) struggle with these altered conditions, which now becomes evident through ongoing declines in diversity, abundance and biomass in grasslands (e.g. Seibold et al. 2019).

The general importance of present landscape structure (e.g. Sirami et al. 2019) and local land-use intensity (e.g. Allan et al. 2014) for the species richness of plants and arthropods are well studied. However, different spatial scales might be important for different taxonomic and functional groups (Honnay et al. 2003). In our study, landscape structure is comprised of landscape composition, i.e. the number and abundance of different land covers, and landscape configuration, i.e. the spatial arrangement of these land covers within a landscape (With 2019). Both can be quantified using landscape metrics (Walz 2011). Plant and arthropod species are suitable target groups for evaluating the relative importance of present and historical landscape structure for biodiversity, because of their essential contribution to many ecological processes and the general differences in their ability to react or be affected by disturbances at different spatiotemporal scales (e.g. active and passive

S. Seibold

Berchtesgaden National Park, Doktorberg 6, 83471 Berchtesgaden, Germany

K. Wells

Department of Biosciences, Swansea University, Swansea SA2 8PP, UK

C. Westphal

Functional Agrobiodiversity, Department of Crop

Sciences, University of Göttingen, Göttingen, Germany 
dispersal), as well as their crucial role in biotic interactions such as plant-pollinator relationships (e.g. DiLeo et al. 2014). Plants with low dispersal ability, for instance, are mainly influenced by local habitat structures, whereas long-distance dispersed plant species are influenced more strongly by landscapescale structures (Damschen et al. 2014; DiLeo et al. 2014; Trakhtenbrot et al. 2014). Li et al. (2020), however, found the species richness of weak and strong dispersing species to be negatively affected by the area-weighted mean of shape metric and the nearest neighbour distribution at larger spatial scales. Complex local structures were found to be favourable for both dispersal types. For arthropod species, Seibold et al. (2019) found the biomass of weak dispersing species to decline with increasing cover of arable fields in the surrounding area, while the biomass of strong dispersing arthropod species was not affected by surrounding arable field cover. When Liu et al. (2014) investigated how landscape structure and local land-use intensity affected functional beetle diversity, they found herbivore, predator and decomposer abundances to be affected by a combination of landscapeand local-scale variables. At the same time, the negative effects of local land-use intensification on species abundance can be mitigated by increasing landscape structure diversity (e.g. Gámez-Virués et al. 2015; Perović et al. 2015; Neff et al. 2019; Wintle et al. 2019).

Most studies focus only on the effects of presentday land use and landscape structure on species diversity, disregarding historical land management changes that may have altered both local land cover and the structure of the surrounding landscape. However, long lasting effects of historical land cover and landscape structure from as long as 150 years ago could still influence present-day species communities (Tilman et al. 1994; Lindborg and Eriksson 2004). For example, some studies showed that the current species richness of grasslands is influenced by past habitat amount (Finnish meadows, Raatikainen et al. 2018) as species show a time lagged response to habitat fragmentation caused by past management decisions (Fahrig 2003; Purschke et al. 2014) and the decrease of habitat amount (Fahrig 2017; Riibak et al. 2020). These examples show that changes in species richness are ongoing and may be strongly intertwined with historical changes of landscape structure.
The extent and time frame of impacts of the historical land cover on current species richness are poorly understood. In an agricultural landscape, using data that extended 60 years into the past, Riibak et al. (2020) found that long-distance dispersing plant species occur more often in areas in which neighbouring patches were historically more persistently covered with grassland. Some calcareous grassland plant species may even be absent from suitable isolated patches due to low dispersal ability across unsuitable matrix habitats over extended time periods (Riibak et al. 2015). Thus, we also expect historical landscape structure to affect species richness in our study.

In this study we examined the effects of present land-use intensity, historical and present land cover and landscape structure on present-day plant and arthropod species richness in semi-natural grasslands of Central Europe. In particular, we analysed how strongly arthropod and plant communities are influenced by historical landscape metrics from three distinct points in time (1820/50, 1910/30, and 1960) relative to present local land-use intensity and landscape metrics measured at the time of plant and arthropod sampling (2008-2016). To better understand what shapes present-day species richness, we additionally analysed species richness of different subsets of plant and arthropod species. These were defined based on taxonomic categories as well as functional traits (i.e. dispersal ability, habitat and feeding specialization, guild, stratum use), which should help improve the understanding of the mechanisms underlying the impact of landscape structure on species' communities (Weiher and Keddy 1995).

We expect species richness to increase with increasing historical patch area the same way species richness is affected by present patch area as shown in other studies (e.g. Dembicz et al. 2020). Furthermore, we expect temporal habitat continuity to have a positive effect on species richness (Veldman et al. 2015; Le Provost et al. 2021). To investigate these expectations, we focused on the following research questions:

(a) Do historical land cover and historical landscape structure affect present species richness across the studied grasslands and what is the relative importance of historical landscape 
structure compared to present landscape structure.

(b) Which historical time periods are most important for the species richness of plants and arthropods?

(c) Which functional groups of plants and arthropods are most strongly affected by historical land use and landscape structure?

\section{Methods and materials}

Study area

The study was conducted within the framework of the Biodiversity Exploratories, comprising three production landscapes in Germany (Fischer et al. 2010). The sampling areas are located in the UNESCO Biosphere Reserve Swabian Alb (Schwäbische Alb, 48 $20^{\prime} 28^{\prime \prime}-$ $48^{\circ} 32^{\prime} 02^{\prime \prime} \mathrm{N}, 9^{\circ} 10^{\prime} 49^{\prime \prime}-9^{\circ} 35^{\prime} 54^{\prime \prime} \mathrm{E}, \sim 422 \mathrm{~km}^{2}$, $460-860 \mathrm{~m}$ asl) in south-western Germany, the National Park Hainich and its surrounding areas (Hainich-Dün, 50 47 $25^{\prime \prime}-51^{\circ} 22^{\prime} 43^{\prime \prime} \mathrm{N}, 10^{\circ} 10^{\prime}$ $24^{\prime \prime}-10^{\circ} 46^{\prime} 45^{\prime \prime} \mathrm{E}, \sim 1300 \mathrm{~km}^{2}, \sim 285-550 \mathrm{~m}$ asl) in central Germany, and the UNESCO Biosphere Reserve Schorfheide-Chorin (52 $47^{\prime} 25^{\prime \prime}-53^{\circ} 13^{\prime} 26^{\prime \prime}$ $\mathrm{N}, 13^{\circ} 23^{\prime} 27^{\prime \prime}-14^{\circ} 08^{\prime} 53^{\prime \prime} \mathrm{E}, \sim 1300 \mathrm{~km}, 3-140 \mathrm{~m}$ asl) in north-eastern Germany (for a map of the regions in Germany see Online Resource 1). In each region, 50 grasslands managed as meadows, pastures or mown pastures were chosen from 500 previously surveyed grid plots, following a stratified random selection (for details see Fischer et al. 2010). The plots were restricted to the two most common soil types in each region, thereby minimizing possible confounding effects in the data. The grasslands were designated as such for at least 10 years before the start of the project in 2006 and represent the regional-specific range of land use. On each grassland, a $50 \mathrm{~m} \times 50 \mathrm{~m}$ plot was established within a larger management unit for detailed species surveys. Details about the grassland management have been collected yearly since 2006 (Vogt et al. 2019).

Species richness and functional groups

Plant species richness was calculated from abundance data collected on 148 of the 150 Biodiversity
Exploratories experimental grassland plots. All plant species were sampled in a $4 \mathrm{~m} \times 4 \mathrm{~m}$ subplot once in spring of 2009 (Socher et al. 2012). Of 347 recorded plant species, 304 were used for the analyses (Table 1). Highly uncharacteristic (e.g. Pinus sp.) and unidentified species (only identified to genus level) were excluded. Arthropod species richness was calculated from yearly sweep-net samples (20 double sweeps along three $50 \mathrm{~m}$ transects, i.e. the plot borders, once in spring and once in summer of each year) of all 150 grassland plots, cumulated over the years 2008 to 2015 to get more robust community data. In our analysis we focused only on the orders Hemiptera (restricted to Heteroptera and Auchenorrhyncha), Coleoptera and Araneae from these samples. Of 1214 recorded species, 1044 species were used in the analyses (Table 1). Species that were highly atypical for grassland habitats were excluded for all arthropod related data (Gossner et al. 2015). Additionally, to represent ground-active arthropods, Araneae and Coleoptera species caught with funnel pitfall traps of $15 \mathrm{~cm}$ diameter (filled with 3\% copper sulphate solution) in the Hainich region were analysed. Three traps were installed on 43 plots of the 50 plots and were emptied monthly from May to October 2008. Two out of three traps were randomly selected per month and further analysed due to trap losses. Individuals were pre-sorted to taxonomic orders in the lab and later identified by taxonomic experts (see Acknowledgements). Of 236 recorded species, 228 species were used in the analyses (Table 1). Again, atypical species were excluded (Gossner et al. 2015).

Besides testing the responses of total plant and arthropod species richness, we analysed species richness for subsets of plant and arthropod communities based on taxonomic (Araneae, Coleoptera, Hemiptera) and functional groups derived from a set of functional traits. For plants, the functional groups were based on species' dispersal abilities, i.e. short, medium, longdistance dispersers, derived from Hodgson et al. (1995), and whether they are mesic grassland species typical of meadows and pastures (phytosociological class Molinio-Arrhenatheretea), or dry grassland species, based on their phytosociological affiliation after Ellenberg et al. (1992). For arthropods, functional groups were based on species' dispersal ability using wing development and flying ability for Coleoptera and only wing development for Hemiptera, as well as on activity ranges and dispersal strategies 
Table 1 Total and mean species richness, standard deviation (SD) and number of plots (n) for vegetation records (i.e. plants) as well as sweep netted and pitfall trapped arthropod samples per region

Calculation of means and standard deviations after conversion of species richness data via the natural logarithm. Shown numbers are exponentiated (base Euler's constant)

\begin{tabular}{|c|c|c|c|}
\hline & Plants & Arthropods (sweep net) & Arthropods (pitfall trap) \\
\hline \multicolumn{4}{|c|}{ Swabian Alb } \\
\hline Total & 196 & 610 & - \\
\hline Mean & 28.64 & 68.9 & - \\
\hline SD & 1.37 & 1.2 & - \\
\hline $\mathrm{n}$ & 50 & 50 & 0 \\
\hline \multicolumn{4}{|l|}{ Hainich } \\
\hline Total & 203 & 567 & 228 \\
\hline Mean & 29.26 & 61.6 & 57.79 \\
\hline SD & 1.39 & 1.35 & 1.17 \\
\hline $\mathrm{n}$ & 49 & 50 & 43 \\
\hline \multicolumn{4}{|c|}{ Schorfheide-Chorin } \\
\hline Total & 171 & 670 & - \\
\hline Mean & 18.52 & 75.0 & - \\
\hline SD & 1.25 & 1.2 & - \\
\hline $\mathrm{n}$ & 49 & 50 & 0 \\
\hline \multicolumn{4}{|c|}{ All regions } \\
\hline Total & 304 & 1044 & 228 \\
\hline Mean & 68.27 & 68.27 & 57.79 \\
\hline SD & 1.28 & 1.28 & 1.17 \\
\hline $\mathrm{n}$ & 148 & 150 & 43 \\
\hline
\end{tabular}

for Araneae (weak, moderate, strong dispersers) as proxies. In addition, species were classified according to their feeding guild (carnivorous, herbivorous, omnivorous) and the main vegetation stratum usage (ground, herb layer), and herbivores were further classified according to their food specialization (polyphagous, oligophagous, monophagous). Trait classification was based on the data published by Gossner et al. (2015). For pitfall trap data, monophagous, oligophagous, herb layer dwelling, and herbivorous functional groups could not be analysed separately due to the low number of species.

Present local land-use-intensity

Present land-use intensity was quantified through a continuous land-use-intensity index (LUI, Table 2), which was calculated for each grassland plot based on main grassland management components according to Blüthgen et al. (2012): mowing (frequency per year), grazing (livestock units $\times$ days of grazing $\mathrm{ha}^{-1}$ year $^{-1}$ ) and fertilization ( $\mathrm{kg}$ total nitrogen $\mathrm{ha}^{-1}$ year $^{-1}$ ). To calculate the LUI, mowing, grazing and fertilization intensity were standardized in relation to its mean depending on the region and then added up.
To calculate the compound LUI index over several years, the above components are first summarised, where for each management type the years are added up after standardising by the mean of management intensity of all focal years, divided by the number of years for each component. Finally the standardised values for the three management types averaged over the years were added and the result was square root transformed to achieve an even distribution (Blüthgen et al. 2012). The intensity of these different components was recorded using standardised questionnaires for the land owners (Vogt et al. 2019). LUI was calculated using the LUI calculation tool (Ostrowski et al. 2020) implemented in BExIS (http://doi.org/10. 17616/R32P9Q). In our modelling approach we calculated the LUI over the years 2006 to 2015 for the sweep net sampled arthropod species richness, 2006 to 2009 for the plant species richness, and 2006 to 2008 for the pitfall trap sampled arthropod species richness. We calculated the mean intensity beginning two or three years (depending on data availability) prior to the arthropod and vegetation sampling, because land-use intensity of the previous years likely affected the species communities. 
Table 2 Landscape metrics and land-use variables used as predictor variables in the base model with descriptions, units and the scale, i.e. level they act upon

\begin{tabular}{|c|c|c|c|}
\hline Landscape metric & Description & Unit & $\begin{array}{l}\text { Spatial } \\
\text { scale }\end{array}$ \\
\hline Patch density & Number of patches per area unit & \#/ha & Landscape \\
\hline Shannon evenness & $\begin{array}{l}\text { Index ranging between } 0 \text { (no diversity of land cover), and } 1 \text { (perfectly even } \\
\text { distribution of land cover classes) }\end{array}$ & None & Landscape \\
\hline Edge density & Sum of length of all grassland patch edges per area unit & $\mathrm{m} / \mathrm{ha}$ & Class \\
\hline $\begin{array}{l}\text { Grassland area } \\
\text { (proportional) }\end{array}$ & Proportion of all grassland patches in an area & $\%$ & Class \\
\hline $\begin{array}{l}\text { Nearest neighbour } \\
\text { distance }\end{array}$ & Averaged smallest distance between grassland patches in an area & $\mathrm{m}$ & Class \\
\hline Shape Index & $\begin{array}{l}\text { Patch irregularity ranges from } 1 \text { (perfectly circular) to infinity (increasingly irregular } \\
\text { shape) }\end{array}$ & None & Class \\
\hline Permanency & Mean patch area (by year) divided by standard deviation of patch area (by year) & None & Class \\
\hline $\begin{array}{l}\text { Variation in field land } \\
\text { use }\end{array}$ & Land-usage index with values between 0 (no grassland) and 3 (permanent grassland) & None & Class \\
\hline $\begin{array}{l}\text { Patch area } \\
\text { (experimental plot) }\end{array}$ & Area of the patch within which the plot of interest is situated & ha & Patch \\
\hline $\begin{array}{l}\text { Land-use-intensity } \\
\text { Index (LUI) }\end{array}$ & Index combining data on grazing, mowing and fertilization & None & Patch \\
\hline
\end{tabular}

Historical and present landscape metrics

For each region, historical maps were available for one period in the nineteenth century and two periods in the twentieth century. Additionally, we used present-day maps. For each of the four time periods, we calculated a set of landscape metrics.

Historical maps from the Swabian Alb were digitized from cadastral maps ("Flurkarten") of 1820, topographic maps (TK25; 1:25,000) from the German Empire of 1910, and topographic maps (TK25, 1:25,000) from the Federal Republic of Germany (BRD) of 1960. Historical maps from the Hainich were digitized from topographic maps (Urmesstischplatten, 1:25,000) of 1850, topographic maps (TK25, 1:25,000) from the German Empire of 1930, and topographic maps (TK10, 1:10,000) from the German Democratic Republic (DDR) of 1960. Historical maps from Schorfheide-Chorin were digitized from topographic maps (Urmesstischblatt, $1: 25,000$ ) of 1850 , topographic maps (TK25, $1: 25,000)$ from the German Empire of 1930, and topographic maps (TK25, 1:25,000) from the German Democratic Republic (DDR) of 1960. Present landcover features for each plot and the surrounding $2 \mathrm{~km}$ were recorded and mapped in 2008 in the field and polygon borders were defined from high resolution $(40 \mathrm{~cm})$ aerial photographs taken in 2009 to increase the accuracy of the maps. Polygon borders did not vary between 2008 and 2009 (Steckel et al. 2014; GámezVirués et al. 2015; Perović et al. 2015).

Using a Geographical Information System (QGIS v. 2.18), every polygon of the historical and present land-cover layers was associated to one of the following land cover classes: grassland, forest, arable, and other according to the available information. For the analysis of the subset of dry grassland plant species, grasslands were further separated into dry and wet grasslands and only dry grasslands were used for modelling (for a comprehensive list of both land-cover keys and their original names and simplifications, see Online Resource 2).

The use of landscape metrics to quantify landscape structure has been well established (e.g. Turner and Gardner 2015) and is widely available as software packages (e.g. FRAGSTATS: McGarigal and Marks 1995, R Statistics: R Core Team 2019). Landscape metrics of the class and landscape spatial scale (Table 2) were calculated for each combination of plot patch and buffer zone $(100 \mathrm{~m}, 250 \mathrm{~m}, 500 \mathrm{~m}$, 
$1000 \mathrm{~m}$ and $2000 \mathrm{~m}$ around the plot centres) and time period (1820/50, 1910/30, 1960, 2008). Permanency and 'variation in field land use' (Table 2) were calculated for each buffer zone.

Statistical analysis

Using the R Statistics Software v. 3.6.1 (R Core Team 2019), we investigated the impact of present and historical land cover and landscape structure on plant and arthropod species richness. We fitted separate generalized linear models (GLMs) for the richness of each subset of species (response variables, i.e. for plants: species richness of all, short, medium, and long dispersing, dry and mesic grassland species; for arthropods: species richness of all, weak, moderate, strong dispersing, carnivorous, herbivorous, omnivorous, polyphagous, oligophagous, monophagous, ground, and herb layer specialist species) with the landscape variables as predictors (Table 2), as well as the regions (except for pitfall trap models) as covariates (base models; Eq. 1).

Response Variable $\sim \beta_{1}+\beta_{2}$ Plot patch area $2008+\beta_{3} L U I+$ $\beta_{4}$ Landscape patch density $+\beta_{5}$ Landscape Shannon Evenness + $\beta_{6}$ Class edge density $+\beta_{7}$ Class area (proportional $)+$

$\beta_{8}$ Class Nearest Neighbour Distance +

$\beta_{9}$ Class Shape Index $+\beta_{10}$ Permanency +

$\beta_{11}$ Variation in field land use $+\beta_{12}$ fRegion

All continuous predictor variables were z-transformed to be able to compare effect sizes. To select the most important buffer radius and year of each landscape metric for use in the base models, GLMs were computed beforehand using only one variant of a certain landscape metric at a time, plus the plot patch area and the covariates LUI and region as predictors. We then selected the best fitting combinations of buffer radius and year of each landscape metric for each subset of species according to the models with the lowest Akaike Information Criterion value.

The final models were produced using model selection (step function in base R). We calculated effect sizes of the predictor variables on the original scale of species richness by raising $e$ to the power of the estimate, which provides the ratio of change in species richness after a change of the predictor by one standard deviation (SD) unit, since the data were z-transformed.
We used Poisson distribution in the GLM, if possible, or negative binomial distribution (function glm.nb from the R package 'MASS' (Venables and Ripley 2002)) in cases where the response variables showed overdispersion. All models were fit with loglink function. Model validation was performed following Zuur et al. (2013). We checked linearity of the relationship between predictors and response variables using scatterplots and Pearson residuals. Further, collinearity was tested observing variance inflation factors (VIF). Variables with VIF-values higher than 5 were excluded (see Online Resource 3) Some significant correlations were observed among the predictor variables, particularly among the variants of the same landscape metrics (see Online Resource 4). However, there was no collinearity in the final models. Finally, we tested for spatial dependence of the model residuals by means of Moran's I and found no case of significant spatial auto-correlation (see Online Resource 5). Various other $\mathrm{R}$ packages were used for geographical data analysis, data wrangling and plotting (see Online Resource 6).

The significance of effects of predictor variables in the final models was tested with type-II Likelihood Ratio Tests using the 'Anova' function from the R-package 'car' (Fox and Weisberg 2019). Additionally, we tested whether the final models that included historical landscape metrics fit better to the data compared to models containing only present landscape metric variables using Vuong tests (Vuong 1989) in order to validate the significance of historical landscape effects.

\section{Results}

Landscape change

Overall grassland area has increased since the nineteenth century by $7 \%$ in the Swabian Alb, by $59 \%$ in the Hainich, and by $24 \%$ in Schorfheide-Chorin, accompanied by an increase in forest area (25-36\%) and a considerable decrease of arable land (38-59\%) across all regions (Fig. 1). On average, all landscape metrics, i.e. patch density, Shannon evenness, proportional grassland area, edge density and shape index, slightly increased over the years, except for nearest grassland neighbour distance. The latter remained relatively constant in the Swabian Alb and the 
Schorfheide-Chorin but continuously decreased by $67.2 \%$ in the Hainich (Fig. 2).

\section{Plant species richness}

Of the 20 selected landscape metrics included in the final models of all the different plant species functional groups, 14 were historical variants. For shortand long-dispersing as well as mesic grassland plant species, models with mixed sets of historical and present landscape metrics fitted the data better compared to models consisting of only present variants (Vuong test, $\mathrm{p}<0.05$ ). For the other functional groups (short distance dispersers and dry grassland species), there was no significant difference among 'mixed' nor 'present' models (Vuong test, $\mathrm{p}>0.05$ ). The time periods most represented in the selected historical landscape variables were $1820 / 50(29.7 \%$ of all significant variables) and 1960 (22.8\%).

Among the functional groups, which were significantly more affected by a mixture of present and historical variables compared to models using only present variables, species richness of plants with short distance dispersal was negatively associated to the landscape patch density of $1820 / 50$ in a radius of $250 \mathrm{~m}(\mathrm{p}<0.01)$ and by the proportion of grassland area in the surrounding $2000 \mathrm{~m}$ of $1820 / 50$ (p $<0.01$; Fig. 3). Furthermore, richness of long-distance dispersing plants was positively affected by the landscape patch density of $1820 / 50$ in a radius of $2000 \mathrm{~m}$ $(\mathrm{p}<0.05)$. The proportional area of grasslands in the surrounding $2000 \mathrm{~m}$ of 1960 had a negative effect on long-distance dispersers $(\mathrm{p}<0.001)$. Mesic grassland specialists were positively correlated to the Shannon evenness of 1960 calculated for the surrounding
$1000 \mathrm{~m}(\mathrm{p}<0.001)$, but negatively to grassland permanency $(\mathrm{p}<0.001)$. As an example, the ratio of change in species richness for mesic grassland specialist species per change of one standard deviation unit (SD) for the Shannon evenness (estimate $)$ was estimated as 1.097, which translates into a higher plant species richness of around 10\% in grasslands with historically higher evenness in the surrounding landscape compared to grasslands with historically less even surrounding landscapes. Likewise, a change in grassland permanency by $1 \mathrm{SD}$ would elicit a decrease in species richness of around $11 \%$.

\section{Arthropod species richness (sweep-net samples)}

For the arthropod species collected via sweep-net sampling, $69 \%$ of all 58 landscape metric combinations selected in the final models were historical variants. For the herbivores (Vuong test, $\mathrm{p}<0.01$ ), weakly and moderately dispersing species (Vuong test for both, $\mathrm{p}<0.05$ ), as well as Coleoptera (Vuong test, $\mathrm{p}<0.05$ ) and Araneae species (Vuong test, $\mathrm{p}<0.01$ ) the models including a mix of historical and present landscape metrics showed a significantly better fit compared to models with exclusively present metrics (Fig. 4). The best performing models included historical landscape metric variants of different periods but the time period of 1960 was most often selected among the significant landscape metric variables of all sweep netted arthropod functional groups.

Species richness of herbivorous arthropods was positively affected by the landscape patch density of $1820 / 50$ in a radius of $2000 \mathrm{~m}(\mathrm{p}<0.001)$ and the nearest neighbour distance of 1910/30 within a radius of $2000 \mathrm{~m}(\mathrm{p}<0.01)$. Species richness of arthropod

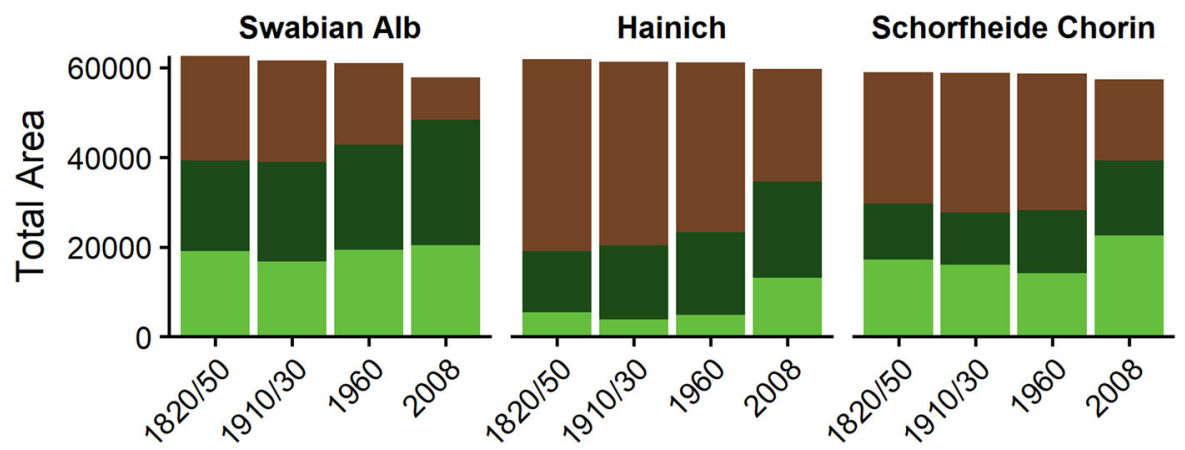

Fig. 1 The change of total area of land cover classes in $\mathrm{km}^{2}$ over the four time periods for the area spanned by a $2000 \mathrm{~m}$ radius around each grassland study plot, shown by region. Brown: arable land, dark green: forest, light green: grassland; land use "other" omitted 


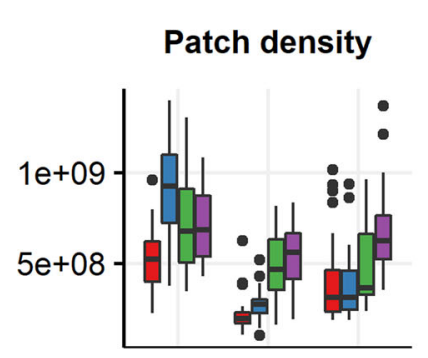

Edge density

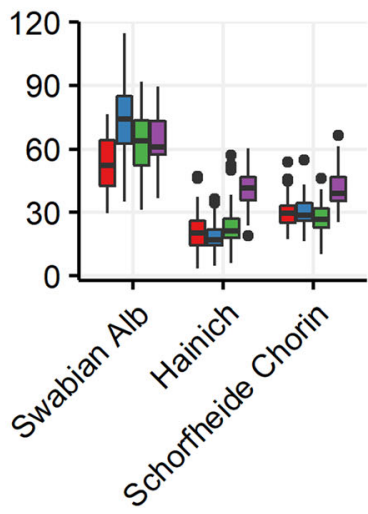

time periods:
Shannon evenness

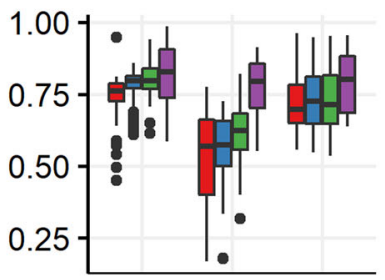

Shape index

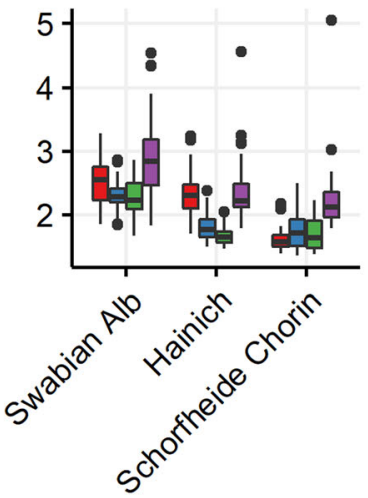

$1820 / 50$

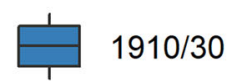

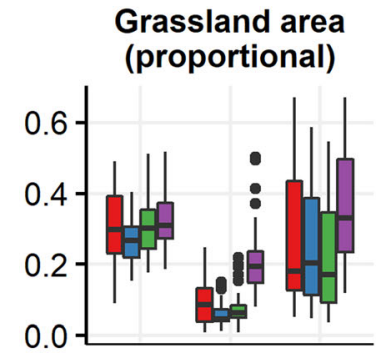

Nearest neighbour distance
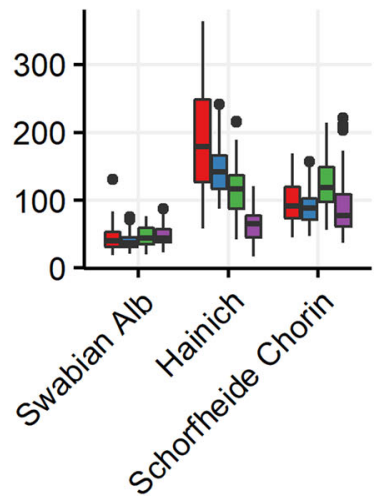

1960

Fig. 2 Range of landscape metrics used in GLMs over time periods at the 2000 m radius: Colours show time periods: red: 1820/50, blue:1910/30, green: 1960 , purple: 2008

species with low dispersal ability was negatively affected by the landscape patch density of 1960 calculated within a radius of $1000 \mathrm{~m}(\mathrm{p}<0.01)$, while the nearest neighbour distance of 1960 calculated within a radius of $500 \mathrm{~m}$ had a positive effect $(\mathrm{p}<0.05)$. Species richness of arthropod species with a moderate dispersal ability was positively affected by the landscape patch density of 1820/50 at a radius of $2000 \mathrm{~m}(\mathrm{p}<0.01)$ and negatively affected by the edge density of 1960 within a radius of $1000 \mathrm{~m}$ $(p<0.01)$. Species richness of Coleopterans was positively affected by the nearest neighbour distance in $2000 \mathrm{~m}$ around the plot of 1910/30 ( $\mathrm{p}<0.01)$. Araneae species richness was negatively related to the edge density within $1000 \mathrm{~m}$ of $1960(\mathrm{p}<0.01)$.

\section{Arthropod species richness (pitfall traps)}

For the pitfall trap samples of ground-active arthropods (Fig. 5), around $78 \%$ of the 63 selected landscape metrics were historical variants. Models of species richness of omnivorous species, and species with either low or high dispersal ability showed a significantly better fit $(\mathrm{p}<0.01)$ with a mixed selection of historical and present variables compared to models with only present variables. The time period most frequently present in the final models was $1820 / 50$.

Omnivore richness was positively correlated with the proportional grassland area of $1820 / 50$ within a radius of $500 \mathrm{~m}(\mathrm{p}<0.001)$ and the shape index within radius of a $2000 \mathrm{~m}$ in 1910/30 ( p < 0.01). Species richness of weak dispersers positively correlated with the edge density within a radius of $500 \mathrm{~m}$ in $1910 / 30(\mathrm{p}<0.01)$ and negative correlated with the patch density within $500 \mathrm{~m}$ of $1820 / 50(\mathrm{p}<0.05)$. Species richness of strong dispersers was positively correlated with the Shannon evenness within $500 \mathrm{~m}$ of $1960(\mathrm{p}<0.05)$ and the edge density within $500 \mathrm{~m}$ of 1820/50 ( $<<0.01$; see Online Resource 7 for a table with modelling parameters and statistical results for all models). 


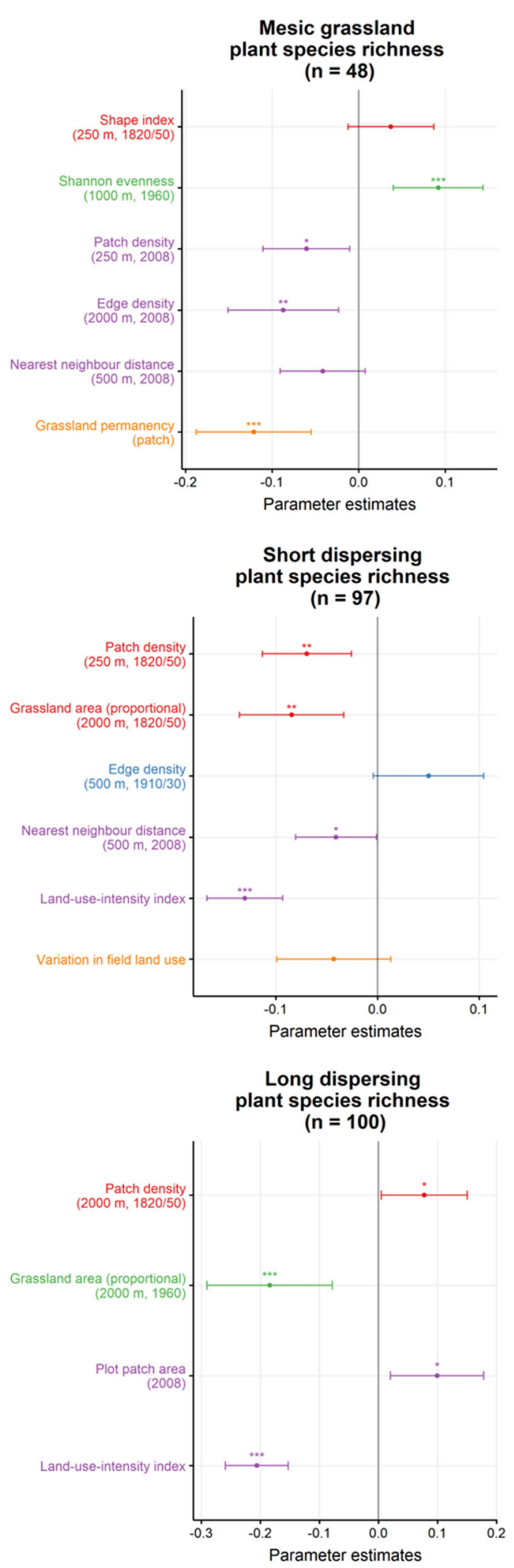

4Fig. 3 Forest plots of plant subsets (all three regions combined) of which the models with historical and present variables fit significantly better compared to models with only present variables (Vuong test). Displayed are the variables included in the final model, their relative effect sizes, standard deviation and significance levels $(* * * \mathrm{p}<0.001, * * \mathrm{p}<0.01, * \mathrm{p}<0.05)$. Colours show time period of variable: red: 1820/50, blue: 1910/30, green: 1960, purple: 2008 and orange: compound variables calculated over all periods. n-values represent numbers of different species

\section{Discussion}

Historical landscape structure strongly affected the present species richness of plants and arthropods in the studied grasslands in the three regions in Germany. Our study revealed that many of the tested plant and arthropod taxonomic and functional groups were not affected by present or historical metrics alone, but by a combination of variables at different time scales. This suggests that species richness cannot exclusively be explained by present landscape conditions, and historical landscape structure of the past 200 years is highly relevant for the species richness that we observe today. However, the impact of the time period and landscape metric differed for each functional group. Therefore, it is necessary to clearly evaluate the effects of the historical landscape from the point of view of the focal communities.

Effect of historical landscape structure on current species richness

The historical grassland area at the local patch level, i.e. the size of the grassland in which the plot is located, had no influence on the local richness of the different subsets of plant and arthropod species. This is in contrast to other studies on the influence of present grassland area which showed an increase in species richness with increasing historical or present patch area (e.g. Dembicz et al. 2020). However, many of the studied grasslands span large, connected, and unregularly shaped areas. This spatial situation is very different from the classical, more or less isolated patches, which are commonly studied (Arrhenius 1921; Ben-Hur and Kadmon 2020). A species-arearelationship, translating into higher plot-level richness on larger grasslands, might exist among the smaller and more compact grassland patches, but remains 

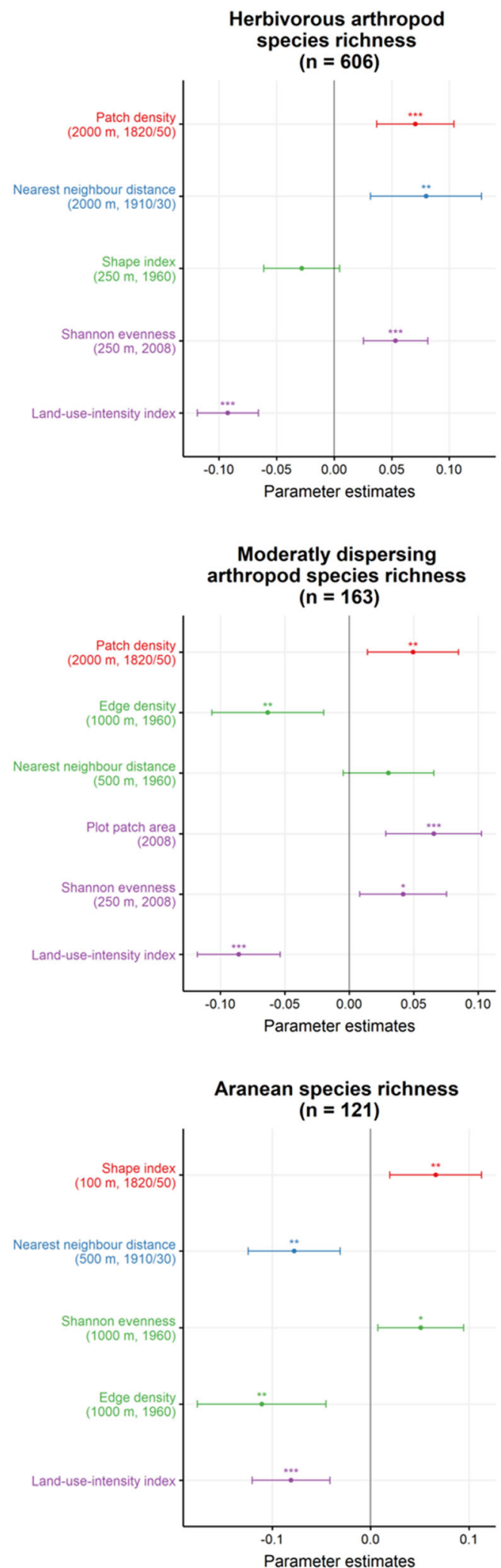

Weakly dispersing arthropod species richness

( $n=90$ )
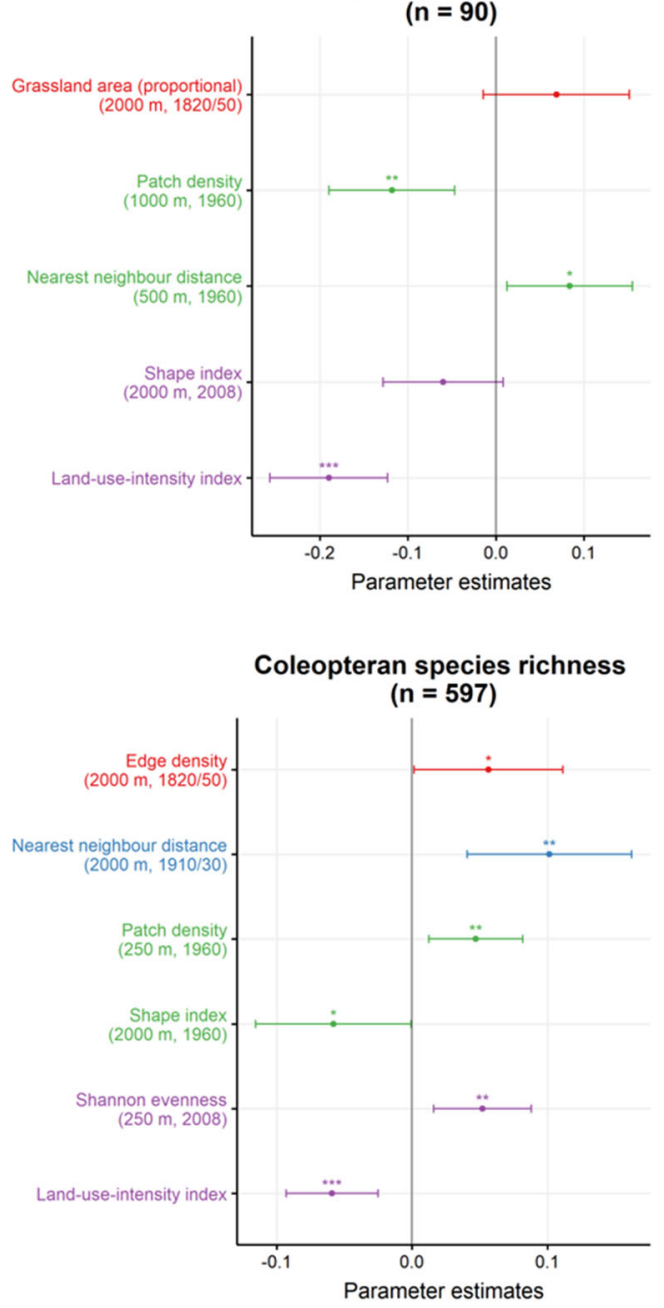
4Fig. 4 Forest plots of all sweep net sampled arthropod subsets (all three regions combined) of which the models with historical and present variables fit significantly better compared to models with only present variables (Vuong test). Displayed are the variables included in the final model, their relative effect sizes, standard deviation and significance levels $(* * * p<0.001$, $* * \mathrm{p}<0.01, * \mathrm{p}<0.05)$. Colours show time period of variable: red: 1820/50, blue: 1910/30, green: 1960, purple: 2008 and orange: compound variables calculated over all periods. n-values represent numbers of different species

undetected by our models. The habitat amount hypothesis (Fahrig 2013) suggests that species richness depends on habitat amount at landscape scale rather than on local patch size. We observed an impact of proportional grassland area at the landscape scale on some of the studied functional groups (see below: "Differences between functional groups" section). In summary, local grassland patch area had a neglectable influence on the studied groups, which is probably mainly due to the arrangement of the patches in the landscape.

Historical landscape patch density played an important role for the studied functional groups. On the one hand, complex landscapes provide habitats for different species and opportunity for locally extinct species to be recruited from the surrounding species pool (Tilman 1997; Tscharntke et al. 2002). On the other hand, high patch density means a high degree of fragmentation of habitats, which may hinder colonisation of dispersal-limited species. These opposed effects of patch density are reflected in our results where, e.g., short dispersing plants were negatively affected, whereas long dispersers showed a positive response to high historical patch density. In general, the importance of historical patch density indicates a time lagged response to changes in landscape structure.

We observed landscape evenness, i.e. the distribution of different land cover classes in the landscape, to operate on a short time frame, as mainly present variables affected the species richness of the functional groups. Increasing evenness decreases disturbance spread and enhances recovery rates of species by providing refuge and facilitating a rescue effect, i.e. recolonization after disturbance (Turner and Gardner 2015). We found little variation in historical evenness corroborating this idea. Uniform landscape composition, for example with single, large arable patches, and a reduced grassland area may have short-term impacts as species dependent on heterogenous landscape not only lose their habitat, but also the ability to recover after heavy disturbances (Waldén et al. 2017).

A high nearest neighbour distance among habitat patches of the same class, i.e. larger distances between grassland patches, may affect species richness negatively by decreasing the likelihood of rescue effects and the chance of species to escape from disturbances and competition through affecting the connectivity of patches (Lindborg and Eriksson 2004; Cousins 2006). Yet nearest neighbour distance could also exert a positive effect by preventing the spread of disturbances (O'Neill et al. 1992). We observed almost exclusively positive effects of historical nearest neighbour distance, i.e. the farther away the grassland neighbours were, the higher the observed species richness. The results might be the consequence of disturbances spreading through better connected, closer patches, or due to a few species-rich remnant patches spread across the landscape with species-poor patches in-between, reducing the nearest neighbour distance and thus causing the observed negative effects.

We found no single most important spatial scale for any of the functional groups studied. Historical and present landscape metrics had significant effects at different radii depending on respective groups. Raatikainen et al. (2018) observed $1 \mathrm{~km}$ to be a meaningful connectivity threshold for meadow plant species, while investigating different connectivity thresholds in past and present landscape structures of Finnish meadows. Long distance dispersing plant species in our study were only impacted by the largest radius of $2 \mathrm{~km}$, as expected for, e.g., zoochorous species (Helm et al. 2006). Short dispersing species are expected to operate on a shorter radius (Soons et al. 2005), which we could not observe consistently. Over longer time periods, different spatial scales may play a role and thus known effects of present landscape metrics on species richness cannot be applied to past situations. Short distance dispersing arthropod species in our study were mainly affected by the 500 to $1000 \mathrm{~m}$ radius, but long-distance dispersers by up to $2000 \mathrm{~m}$. As opposed to plants, arthropod dispersal is usually an active process (informed dispersal, Clobert et al. 2009), where dispersal is dependent on habitat availability, detection ability of suitable habitats, as well as population density and resource availability in 

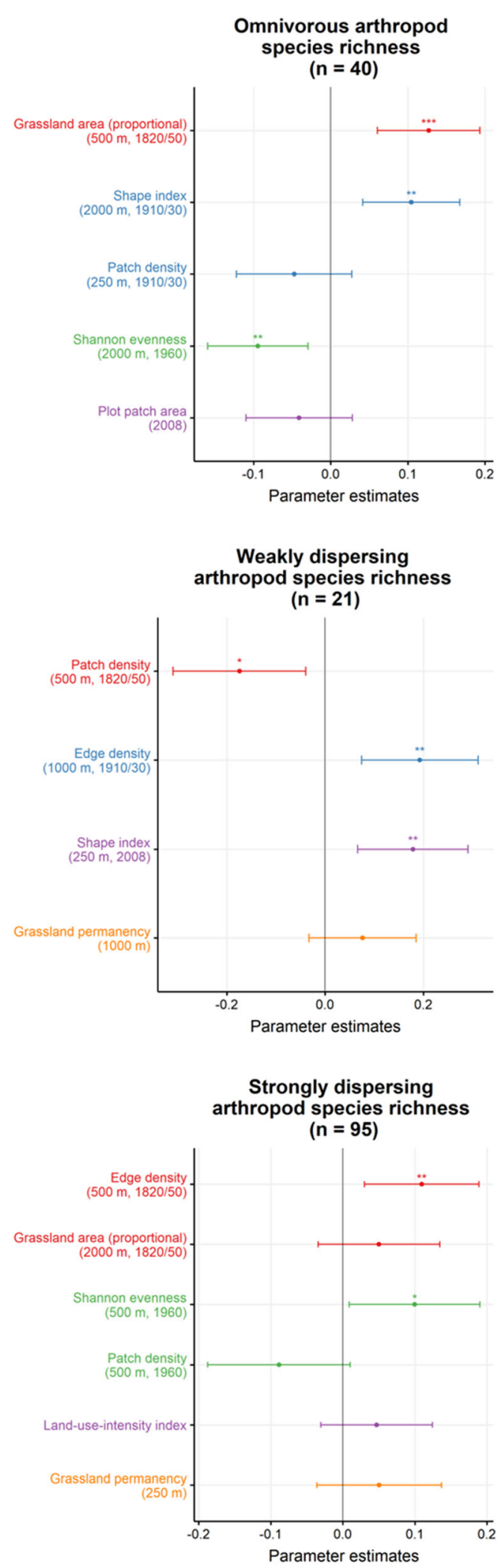

४Fig. 5 Forest plots of all pitfall trap sampled arthropod subsets (only Hainich region) of which the models with historical and present variables fit significantly better compared to models with only present variables (Vuong test). Displayed are the variables included after model averaging, their relative effect sizes, standard deviation and significance levels $(* * * \mathrm{p}<0.001$, $* * \mathrm{p}<0.01, * \mathrm{p}<0.05)$. Colours show time period of variable: red: 1820/50, blue: 1910/30, green: 1960, purple: 2008 and orange: compound variables calculated over all periods. $\mathrm{n}$-values represent numbers of different species

the current landscape (Lima and Zollner 1996; Poethke and Hovestadt 2002). Our results show that a higher dispersal ability, seemingly irrespective of dispersal being an active or passive process, results in a dependency on larger landscape scales. Although theoretically the dispersal limitation of species with low dispersal abilities by local landscape structures is more or less well understood (e.g. Tilman 1994; Ozinga et al. 2005), we have not found a clear scale dependency in our study.

Effect of historical local land cover on current species richness

Regarding local land cover, we expected temporal habitat continuity to have a positive effect on species richness (Veldman et al. 2015). However,'variation in field land use' was only selected in the final model for weak dispersing plant species and did not have a significant effect. Le Provost et al. (2021) revealed comparable results for 'variation in field land use' in a study on different trophic groups of above- and belowground species, whereas other European studies have shown that grassland specialist plant species of the vegetation class Molinio-Arrhenatheretea are positively affected by temporal habitat continuity (Raduła et al. 2020) and that saproxylic weevil frequency is higher in old woodland (Buse 2012). Colonization of habitat patches depends on both the connectivity of the patch and the conditions of the patch (i.e. land-use intensity in our study). As our grasslands fall along gradients of those confounding factors, this could explain the lack of clear patterns regarding habitat continuity in our study.

The semi-natural grassland specialist plants of the phytosociological class Molinio-Arrhenatheretea were negatively affected by grassland permanency, i.e. grassland area changes over time. This is most 
likely an indirect effect, facilitated by high historical land-use intensity on sites with high grassland permanency. However, due to the lack of data on historical land-use intensity, this assumption could not be tested in our study.

Importance of distinct historical time periods

The most important time period, i.e. the period most often included and significant as a coefficient in the GLMs, was 1820/50 (30\%), followed by 1960 (23\%) and finally 1910/30 (20\%). Present variables were almost as important (28\%) as our oldest time period. Other studies have identified historical land use in the past 100 to 150 years to be an important driver shaping the composition of calcareous grassland communities (Heubes et al. 2011), plant community traits (Purschke et al. 2014), and arthropod seed predator communities (Stuhler and Orrock 2016). Our work underlines the importance of historical landscape metrics covering almost 200 years for studies on current species richness, and that a combination of past and present variables best explains species richness, but also that the influence of a distinct time period is communityand landscape metric-specific. However, it is not entirely clear why the landscape metrics from the $1820 / 50$ period appeared to be more important than the other two periods included in our study.

\section{Differences between functional groups}

Plants of the phytosociological class of the MolinioArrhenatheretea, short and long dispersing plants, herbivorous, low to intermediately dispersing arthropods from the sweep net samples, beetles and spiders, as well as omnivorous, and weakly and strongly dispersing pitfall trapped arthropods were all more strongly affected by historical metrics than the other functional groups studied. In addition, the direction of effects of historical landscape metrics on group richness differed between differently sampled organisms. For example, the effect of proportional grassland area was different for the three species groups: plants, pitfall trapped arthropods and sweep net sampled arthropods. Increased habitat area should increase species richness, but if larger grassland areas were used more intensively in the past or present, as we suggested above, there may be a negative correlation. Pitfall trapped species were exclusively positively affected by historical and present proportional area of grasslands in the surrounding landscape. Potentially because these were positively affected by a higher land-use intensity in the surrounding landscape, which we cannot test with our data. In contrast, plant species richness correlated negatively with the historical grassland area, which we assume to be an indirect effect of higher intensity of grassland use at present and, possibly, already in the past. Sweep net sampled arthropods, except for monophagous species, which should be strongly related to the availability of plants, were not affected by the proportional grassland area. In our modelling approach we always included present land-use intensity as a candidate predictor variable to control for its strong effects on present species richness and, thus, to allow the other coefficients to show their effects independently of current intensity. Although we could not detect collinearity between predictor variables in the final models, we must assume some correlation between land-use intensity and proportional grassland area exists.

\section{Conclusions}

Our study showed that both historical and present landscape structure affect the richness of arthropods and plants, but effects differ between functional groups according to their habitat requirements and dispersal ability. The effects of historical landscapes appeared to be long lasting and to remain for up to almost 200 years. Historical landscape components remained important even when accounting for current land-use intensity. In particular, grassland specialist plant species (Molinio-Arrhenatheretea) and arthropod species with low to intermediate dispersal abilities showed strong responses to historical landscape structure. In contrast to the spatial variables, the chronological sequence of local land cover classes seems to have little impact on current species richness. The importance of historical landscapes for current species diversity indicates that historical data should, thus, be considered in conservation planning and management. Nature conservation projects should for example use information on past landscape development and consider its effects on species diversity when planning for suitable landscape structures and to improve management strategies. This might help to prevent an ongoing loss of diversity. Our results 
further suggest that responses to historical land use strongly depend on species specific traits, which need to be known to identify the optimal landscape structure for a conservation focus taxon. Future research should explore this aspect and the underlying mechanisms in more detail to provide support for halting the current biodiversity loss.

Acknowledgements We are grateful to two anonymous reviewers for their comments. We thank the implementing managers of the Exploratories, Sonja Gockel, Andreas Hemp and all former managers for their work in maintaining the plot and project infrastructure; Simone Pfeiffer for giving support through the central office, Jens Nieschulze for managing the central data base, and Eduard Linsenmair, Dominik Hessenmöller, Ingo Schöning, François Buscot, Ernst-Detlef Schulze, and the late Elisabeth Kalko for their role in setting up the Biodiversity Exploratories project. We thank Ellen Sperr, Esther Kowalski, Kaspar Kremer, Lara Braun, Michael Ehrhardt, Luis Sikora, Manfred Türke, Michael Ehrhardt and Steffen Both for conducting arthropod sampling in the field, Marco Lutz, Jasmin Bartezko, Monika Plaga, Petra Freynhagen and all student helpers for arthropod sorting in the laboratory; Roland Achtziger, Teo Blick, Boris Büche, Michael Fritze, Ralf Heckmann, Torben Kölkebeck, Carsten Morkel, Franz Schmolke, Thomas Wagner and Oliver Wiche for arthropod species identification. Metke Lilienthal and Julia Dolezil helped digitizing cadastral maps of the Swabian Alb. The work has been (partly) funded by the Deutsche Forschungsgemeinschaft (DFG) Priority Program 1374 "Infrastructure-BiodiversityExploratories" (Project Number 324399761) and partly by the Swiss National Science Foundation (310030E-173542/1). Field work permits were issued by the responsible state environmental offices of Baden-Württemberg, Thüringen, and Brandenburg. $\mathrm{CW}$ is grateful for being funded by the DFG (Project Number 405945293).

Author contributions Not applicable.

Funding Open Access funding enabled and organized by Projekt DEAL. The work has been (partly) funded by the DFG Priority Program 1374 "Infrastructure-BiodiversityExploratories" (Project Number 324399761). CW was funded by the Deutsche Forschungsgemeinschaft (DFG) (Project Number 405945293).

Data availability The datasets generated during and/or analysed during the current study are not publicly available due to an embargo period to protect young researchers but are available from the corresponding author on reasonable request. The datasets will eventually be available via https://www.bexis. uni-jena.de/sws/PublicDataLink.

Code availability The code created by the authors during the current study are available from the corresponding author on reasonable request. A comprehensive list of $\mathrm{R}$ packages used can be found in the Online Resource 6.

\section{Declarations}

Conflict of interest The authors have no conflicts of interest to declare that are relevant to the content of this article.

Ethical approval Not applicable.

Consent to participate Not applicable.

Consent for publication Not applicable.

Open Access This article is licensed under a Creative Commons Attribution 4.0 International License, which permits use, sharing, adaptation, distribution and reproduction in any medium or format, as long as you give appropriate credit to the original author(s) and the source, provide a link to the Creative Commons licence, and indicate if changes were made. The images or other third party material in this article are included in the article's Creative Commons licence, unless indicated otherwise in a credit line to the material. If material is not included in the article's Creative Commons licence and your intended use is not permitted by statutory regulation or exceeds the permitted use, you will need to obtain permission directly from the copyright holder. To view a copy of this licence, visit http://creativecommons.org/licenses/by/4.0/.

\section{References}

Allan E, Bossdorf O, Dormann CF, Prati D, Gossner MM, Tscharntke T, Blüthgen N, Bellach M, Birkhofer K, Boch S, Böhm S, Börschig C, Chatzinotas A, Christ S, Daniel R, Diekötter T, Fischer C, Friedl T, Glaser K, Hallmann C, Hodac L, Hölzel N, Jung K, Klein AM, Klaus VH, Kleinebecker T, Krauss J, Lange M, Morris EK, Müller J, Nacke H, Pašalic E, Rukkug MC, Rothenwährer C, Schall P, Scherber C, Schulze W, Socher SA, Steckel J, SteffanDewenter I, Türke M, Weiner CN, Werner M, Westphal C, Wolters V, Wubet T, Gockel S, Gorke M, Hemp A, Renner SC, Schöning I, Pfeiffer S, König-Ries B, Buscot F, Linsenmair KE, Schulze ED, Weisser WW, Fischer M (2014) Interannual variation in land-use intensity enhances grassland multidiversity. Proc Natl Acad Sci USA 111:308-313

Arrhenius O (1921) Species and area. J Ecol 9:95-99

Ben-Hur E, Kadmon R (2020) Disentangling the mechanisms underlying the species-area relationship: a Mesocosm experiment with annual plants. J Ecol 108:2376

Biró M, Czúcz B, Horváth F, Révész A, Csatári B, Molnár Z (2013) Drivers of grassland loss in Hungary during the post-socialist transformation (1987-1999). Landsc Ecol 28:789-803

Blüthgen N, Dormann CF, Prati D, Klaus VH, Kleinebecker T, Hölzel N, Alt F, Boch S, Gockel S, Hemp A, Müller J, Nieschulze J, Renner SC, Schöning I, Schumacher U, Socher SA, Wells K, Birkhofer K, Buscot F, Oelmann Y, Rothenwährer C, Scherber C, Tscharntke T, Weiner CN, Fischer M, Kalko EKV, Linsenmair KE, Schulze E-D, 
Weisser WW (2012) A quantitative index of land-use intensity in grasslands: integrating mowing, grazing and fertilization. Basic Appl Ecol 13:207-220

Buse J (2012) "Ghosts of the past": flightless saproxylic weevils (Coleoptera: Curculionidae) are relict species in Ancient Woodlands. J Insect Conserv 16:93-102

Clobert J, Le Galliard JF, Cote J, Meylan S, Massot M (2009) Informed dispersal, heterogeneity in animal dispersal syndromes and the dynamics of spatially structured populations. Ecol Lett 12:197-209

Cousins SAO (2006) Plant species richness in midfield islets and road verges-the effect of landscape fragmentation. Biol Conserv 127:500-509

Damschen EI, Baker DV, Bohrer G, Nathan R, Orrock JL, Turner JR, Brudvig LA, Haddad NM, Levey DJ, Tewksbury JJ (2014) How fragmentation and corridors affect wind dynamics and seed dispersal in open habitats. Proc Natl Acad Sci USA 111:3484-3489

Dembicz I, Velev N, Boch S, Janišová M, Palpurina S, Pedashenko H, Vassilev K, Dengler J (2020) Drivers of plant diversity in bulgarian dry grasslands vary across spatial scales and functional-taxonomic groups. J Veg Sci 32:e12935

Diekmann M, Andres C, Becker T, Bennie J, Blüml V, Bullock JM, Culmsee H, Fanigliulo M, Hahn A, Heinken T, Leuschner C, Luka S, Meißner J, Müller J, Newton A, Peppler-Lisbach C, Rosenthal G, Van Den Berg LJL, Vergeer P, Wesche K (2019) Patterns of long-term vegetation change vary between different types of semi-natural grasslands in Western and Central Europe. J Veg Sci 30:187-202

Dileo MF, Siu JC, Rhodes MK, López-Villalobos A, Redwine A, Ksiazek K, Dyer RJ (2014) The gravity of pollination: integrating at-site features into spatial analysis of contemporary pollen movement. Mol Ecol 23:3973-3982

Ellenberg H, Weber HE, Düll R, Wirth V, Werner W, Paulißen D (1992) Zeigerwerte Von Pflanzen In Mitteleuropa, 2nd edn. Lehrstuhl Für Geobotanik Der Universität Göttingen, Göttingen

Fahrig L (2003) Effects of habitat fragmentation on biodiversity. Annu Rev Ecol Evolut Syst 34:487-515

Fahrig L (2013) Rethinking patch size and isolation effects: the habitat amount hypothesis. J Biogeogr 40:1649-1663

Fahrig L (2017) Ecological responses to habitat fragmentation Per Se. Annu Rev Ecol Evolut Syst 48:1-23

Fischer M, Bossdorf O, Gockel S, Hänsel F, Hemp A, Hessenmöller D, Korte G, Nieschulze J, Pfeiffer S, Prati D (2010) Implementing large-scale and long-term functional biodiversity research: the biodiversity exploratories. Basic Appl Ecol 11:473-485

Fox J, Weisberg S (2019) An R companion to applied regression, 3rd edn. Sage, Thousand Oaks, CA

Gámez-Virués S, Perović DJ, Gossner MM, Börschig C, Blüthgen N, De Jong H, Simons NK, Klein A-M, Krauss J, Maier G (2015) Landscape simplification filters species traits and drives biotic homogenization. Nat Commun 6:8568

Gossner MM, Simons NK, Achtziger R, Blick T, Dorow WH, Dziock F, Köhler F, Rabitsch W, Weisser WW (2015) A summary of eight traits of coleoptera, hemiptera, orthoptera and araneae, occurring in grasslands in Germany. Sci Data 2:150013

Habel JC, Dengler J, Janišová M, Török P, Wellstein C, Wiezik M (2013) European grassland ecosystems: threatened hotspots of biodiversity. Biodivers Conserv 22:2131-2138

Helm A, Hanski I, Pärtel M (2006) Slow response of plant species richness to habitat loss and fragmentation. Ecol Lett 9:72-77

Heubes J, Retzer V, Schmidtlein S, Beierkuhnlein C (2011) Historical land use explains current distribution of calcareous grassland species. Folia Geobot 46:1-16

Hodgson J, Grime J, Hunt R, Thompson K (1995) The electronic comparative plant ecology. Springer, Berlin

Honnay O, Piessens K, Van Landuyt W, Hermy M, Gulinck H (2003) Satellite based land use and landscape complexity indices as predictors for regional plant species diversity. Landsc Urban Plann 63:241-250

Le Provost G, Thiele J, Westphal C, Penone C, Allan E, Neyret M, Van Der Plas F, Ayasse M, Bardgett RD, Birkhofer K, Boch S, Bonkowski M, Buscot F, Feldhaar H, Gaulton R, Goldmann K, Gossner MM, Klaus VH, Kleinebecker T, Krauss J, Renner S, Scherreiks P, Sikorski J, Baulechner D, Blüthgen N, Bolliger R, Börschig C, Busch V, Chisté M, Fiore-Donno AM, Fischer M, Arndt H, Hoelzel N, John K, Jung K, Lange M, Marzini C, Overmann J, Paŝalić E, Perović DJ, Prati D, Schäfer D, Schöning I, Schrumpf M, Sonnemann I, Steffan-Dewenter I, Tschapka M, Türke M, Vogt J, Wehner K, Weiner C, Weisser W, Wells K, Werner M, Wolters V, Wubet T, Wurst S, Zaitsev AS, Manning P (2021) Contrasting responses of above-and belowground diversity to multiple components of land-use intensity. Nat Commun 12:1-13

Li Z, Han H, You H, Cheng X, Wang T (2020) Effects of local characteristics and landscape patterns on plant richness: a multi-scale investigation of multiple dispersal traitS. Ecol Ind 117:10

Lima SL, Zollner PA (1996) Towards a behavioral ecology of ecological landscapes. Trends Ecol Evol 11:131-135

Lindborg R, Eriksson O (2004) Historical landscape connectivity affects present plant species diversity. Ecology 85:1840-1845

Liu Y, Rothenwöhrer C, Scherber C, Batáry P, Elek Z, Steckel J, Erasmi S, Tscharntke T, Westphal C (2014) Functional beetle diversity in managed grasslands: effects of region, landscape context and land use intensity. Landsc Ecol 29:529-540

Mcgarigal K, Marks BJ (1995) Spatial pattern analysis program for quantifying landscape structure. Gen. Tech. Rep. PnwGtr-351. Us Department Of Agriculture, Forest Service, Pacific Northwest Research Station, pp. 1-122.

Neff F, Blüthgen N, Chisté MN, Simons NK, Steckel J, Weisser WW, Westphal C, Pellissier L, Gossner MM (2019) Crossscale effects of land use on the functional composition of herbivorous insect communities. Landsc Ecol 34:2001-2015

O'neill RV, Gardner RH, Turner MG, Romme WH (1992) Epidemology theory and disturbance spread on landscapes. Landsc Ecol 7:19-26

Ostrowski A, Lorenzen K, Petzold E, Schindler S (2020) Land Use Intensity Index (Lui) Calculation tool of the biodiversity exploratories project for grassland survey data from 
three different regions in Germany since 2006. Zenodo. https://doi.org/10.5281/zenodo.3865579

Ozinga WA, Schaminée JHJ, Bekker RM, Bonn S, Poschlod P, Tackenberg O, Bakker J, Groenendael JMV (2005) Predictability of plant species composition from environmental conditions is constrained by dispersal limitation. Oikos 108:555-561

Pärtel M, Bruun HH, Sammul M (2005) Biodiversity in temperate European Grasslands: origin and conservation. Grassl Sci Eur 10:14

Perović D, Gámez-Virués S, Börschig C, Klein AM, Krauss J, Steckel J, Rothenwöhrer C, Erasmi S, Tscharntke T, Westphal C (2015) Configurational landscape heterogeneity shapes functional community composition of grassland butterflies. J Appl Ecol 52:505-513

Poethke HJ, Hovestadt T (2002) Evolution of density-and patch-size-dependent dispersal rates. Proc R Soc Lond Ser b: Biol Sci 269:637-645

Purschke O, Sykes MT, Poschlod P, Michalski SG, Römermann C, Durka W, Kühn I, Prentice HC (2014) Interactive effects of landscape history and current management on dispersal trait diversity in grassland plant communities. J Ecol 102:437-446

R Core Team (2019) R: a language and environment for statistical computing. R Foundation For Statistical Computing, Vienna

Raatikainen KJ, Oldén A, Käyhkö N, Mönkkönen M, Halme P (2018) Contemporary spatial and environmental factors determine vascular plant species richness on highly fragmented meadows in Central Finland. Landsc Ecol 33:2169-2187

Raduła MW, Szymura TH, Szymura M, Swacha G, Kącki Z (2020) Effect of environmental gradients, habitat continuity and spatial structure on vascular plant species richness in semi-natural grasslands. Agric Ecosyst Environ 300:106974

Riibak K, Reitalu T, Tamme R, Helm A, Gerhold P, Znamenskiy S, Bengtsson K, Rosén E, Prentice HC, Pärtel M (2015) Dark diversity in dry calcareous grasslands is determined by dispersal ability and stress-tolerance. Ecography 38:713-721

Riibak K, Bennett JA, Kook E, Reier U, Tamme R, Bueno CG, Partel M (2020) Drivers of plant community completeness differ at regional and landscape scales. Agric Ecosyst Environ 301:9

Seibold S, Gossner MM, Simons NK, Blüthgen N, Müller J, Ambarli D, Ammer C, Bauhus J, Fischer M, Habel JC, Linsenmair KE, Nauss T, Penone C, Prati D, Schall P, Schulze ED, Vogt J, Wöllauer S, Weisser WW (2019) Arthropod decline in grasslands and forests is associated with landscape-level drivers. Nature 574:671

Sirami C, Gross N, Baillod AB, Bertrand C, Carrié R, Hass A, Henckel L, Miguet P, Vuillot C, Alignier A, Girard J, Batáry P, Clough Y, Violle C, Giralt D, Bota G, Bandenhausser I, Lefebvre G, Gauffre B, Vialatte A, Calatayud F, Gil-Tena A, Tischendorf L, Mitchell S, Lindsay K, Georges R, Hilaire S, Recasens J, Solé-Senan XO, Robleno I, Bosch J, Barrientos JA, Ricarte A, Marcos-Garcia MÁ, Minano J, Mathevet R, Gibon A, Baudry J, Balent G, Poulin B, Burel F, Tscharntke T, Bretagnolle V, Siriwardena G, Ouin A, Brotons L, Martin J-L, Fahrig L (2019)
Increasing crop heterogeneity enhances multitrophic diversity across agricultural regions. Proc Natl Acad Sci USA 116:16442-16447

Socher SA, Prati D, Boch S, Müller J, Klaus VH, Hölzel N, Fischer M (2012) Direct and productivity-mediated indirect effects of fertilization, mowing and grazing on grassland species richness. J Ecol 100:1391-1399

Soons MB, Messelink JH, Jongejans E, Heil GW (2005) Habitat fragmentation reduces grassland connectivity for both short-distance and long-distance wind-dispersed forbs. J Ecol 93:1214-1225

Steckel J, Westphal C, Peters MK, Bellach M, Rothenwoehrer C, Erasmi S, Scherber C, Tscharntke T, Steffan-Dewenter I (2014) Landscape composition and configuration differently affect trap-nesting bees, wasps and their antagonists. Biol Conserv 172:56-64

Stuhler JD, Orrock JL (2016) Past agricultural land use and present-day fire regimes can interact to determine the nature of seed predation. Oecologia 181:463-473

Tilman D (1994) Competition and biodiversity in spatially structured habitats. Ecology 75:2-16

Tilman D (1997) Community invasibility, recruitment limitation, and grassland biodiversity. Ecology 78:81-92

Tilman D, May RM, Lehman CL, Nowak MA (1994) Habitat destruction and the extinction debt. Nature 371:65-66

Trakhtenbrot A, Katul GG, Nathan R (2014) Mechanistic modeling of seed dispersal by wind over hilly terrain. Ecol Model 274:29-40

Tscharntke T, Steffan-Dewenter I, Kruess A, Thies C (2002) Contribution of small habitat fragments to conservation of insect communities of grassland-cropland landscapes. Ecol Appl 12:354-363

Turner MG, Gardner RH (2015) Landscape ecology in theory and practice: pattern and process, 2 nd edn. Springer, New York

Veldman JW, Buisson E, Durigan G, Fernandes GW, Le Stradic S, Mahy G, Negreiros D, Overbeck GE, Veldman RG, Zaloumis NP, Putz FE, Bond WJ (2015) Toward an oldgrowth concept for grasslands, Savannas, and woodlands. Front Ecol Environ 13:154-162

Venables WN, Ripley BD (2002) Modern applied statistics with $S$, 4th edn. Springer, New York

Vogt J, Klaus VH, Both S, Fürstenau C, Gockel S, Gossner MM, Heinze J, Hemp A, Hölzel N, Jung K, Kleinebecker T, Lauterbach R, Lorenzen K, Ostrowski A, Otto N, Prati D, Renner S, Schumacher U, Seibold S, Simons NK, Steitz I, Teuscher M, Thiele J, Weithmann S, Wells K, Wiesner K, Ayasse M, Blüthgen N, Fischer M, Weisser WW (2019) Eleven years' data of grassland management in Germany. Biodivers Data J 7:e36387

Vuong QH (1989) Likelihood ratio tests for model selection and non-nested hypotheses. Econom $\mathrm{J}$ Econom Soc 57:307-333

Waldén E, Öckinger E, Winsa M, Lindborg R (2017) Effects of landscape composition, species pool and time on grassland specialists in restored semi-natural grasslands. Biol Conserv 214:176-183

Walz U (2011) Landscape structure, landscape metrics and biodiversity. Living Rev Landsc Res 5:1-35 
Weiher E, Keddy PA (1995) Assembly rules, null models, and trait dispersion: new questions from old patterns. Oikos 74:159-164

Wintle BA, Kujala H, Whitehead A, Cameron A, Veloz S, Kukkala A, Moilanen A, Gordon A, Lentini PE, Cadenhead NCR, Bekessy SA (2019) Global synthesis of conservation studies reveals the importance of small habitat patches for biodiversity. Proc Natl Acad Sci USA 116:909-914

With KA (2019) Essentials of landscape ecology. Oxford University Press, Oxford
Zuur AF, Hilbe JM, Ieno EN (2013) A beginner's guide to Glm and Glmm with R: a Frequentist and Bayesian perspective For ecologists. Highland Statistics Limited, Newburgh

Publisher's Note Springer Nature remains neutral with regard to jurisdictional claims in published maps and institutional affiliations. 